Jurnal Penyuluhan, Maret 2010 Vol. 6 No.1

\title{
Model Pengembangan Kompetensi Penyuluh \\ Berbasis Pemanfaatan Media \\ (Kasus Di Kabupaten Karawang dan Garut, Provinsi Jawa Barat)
}

\section{Model of Competency Development Based on Media Utilization of Extension Worker (Case in Karawang and Garut District, West Java)}

\author{
E. Oos M. Anwas ${ }^{1}$, Sumardjo², Pang S. Asngari ${ }^{2}$, Prabowo Tjitropranoto ${ }^{2}$ \\ ${ }^{1}$ Kementerian Pendidikan Nasional \\ ${ }^{2}$ Dept. Sains Komunikasi dan Pengembangan Masyarakat FEMA IPB
}

\begin{abstract}
The present study was to the degree of agricultural extension agents' competency, the dominant factors influence their competency, and also to formulate the model for developing the competency of agricultural extension agents. The study used explanatory research method on 170 agricultural extension agents who work within paddy farmers area (Karawang) and within vegetable farmers area (Garut). Samples from paddy farmers area were taken by using random sampling technique, while those from vegetable farmers area were taken by using census method. Then a data verification was conducted toward 206 farmers who were the clients of the agricultural extension agents. Data collection was conducted during February to April 2009. Data were analyzed using descriptive technique and path analysis. The result of the study showed that the extent of media utilization and the agricultural extension agents' competency tended to be at a low level. Several dominant factors influenced their their competences.
\end{abstract}

Keyword: agricultural extension agents, mass media, programmed media, environmental media, competencies

\section{PENDAHULUAN}

Dinamika masyarakat terus berkembang sebagai akibat dari kemajuan zaman. Kemajuan ilmu pengetahuan terutama teknologi informasi dan komunikasi telah berakibat pada perubahan dalam setiap aspek kehidupan manusia, termasuk dalam sektor pertanian. Ancaman global warning, globalisasi, kerawanan pangan, atau perubahan lingkungan baik lingkungan alam, sosial, dan budaya menambah semakin kencangnya hembusan angin perubahan.

Dalam birokrasi pemerintahan, otonomi daerah memunculkan perubahan dan permasalahan dalam penyuluhan, di antaranya: (1) adanya kesalahan persepsi bagi para penyelenggara penyuluhan di daerah, (2) citra penyuluhan dianggap masih kurang baik, (3) apriori di kalangan masyarakat tertentu terhadap penyuluhan, (4) di masa lalu penyuluhan terwarnai oleh muatan politik organisasi politik tertentu, dan (5) di era otonomi penyuluhan ditinggalkan oleh sebagian penguasa daerah (Sumardjo, 2006). Lahirnya Undang-Undang Nomor 16 tahun 2006 tentang Sistem Penyuluhan Pertanian, Perikanan

\footnotetext{
${ }^{1}$ Korespondensi Penulis: 08159323733
} 
dan Kehutanan menimbulkan keragaman penafsiran dan pelaksanaan penyuluhan di daerah-daerah.

Secara lebih khusus ilmu penyuluhan merupakan multidisiplin dari ilmu-ilmu sosial juga berkembang sesuai perubahan dalam masyarakat. Perkembangan ilmu penyuluhan dari pendekatan top down berkembang menjadi partisipatif dengan memberikan kesempatan pada masyarakat untuk aktif seluas-luasnya dalam memecahkan masalahmasalah yang mereka hadapi (Sumardjo, 1999). Tingginya tuntutan perubahan penyuluhan idealnya ditunjang oleh tenaga penyuluh yang profesional, akan tetapi saat ini masih belum cukup (Slamet, 2008).

Untuk memenuhi tuntutan perubahan zaman ini tidak ada upaya lain bagi penyuluh kecuali harus belajar secara berkelanjutan. Belajar dalam hal ini tidak hanya terbatas pada pendidikan formal, tetapi juga pendidikan non formal dan informal. Hal ini sangat dimungkinkan, karena di era kemajuan teknologi informasi dan komunikasi banyak media belajar yang dirancang secara khusus (by design) maupun yang dapat dimanfatkan (by utilization) untuk proses pembelajaran.

Dengan cara tersebut penyuluh dapat belajar tanpa harus bergantung pada pendidikan formal, mengikuti pelatihan atau menunggu perintah (tugas belajar) dari lembaga penyuluhan yang sangat terbatas. Dengan kata lain penyuluh dituntut memiliki kemandirian belajar melalui pemanfaatan berbagai media sehingga mampu memenuhi tuntutan perubahan zaman. Oleh karena itu menarik untuk dilakukan penelitian tentang pengembangan kompetensi penyuluh berbasis pemanfaatan media. Atas dasar pemikiran dan asumsi-asumsi di atas, permasalahannya adalah: bagaimana tingkat kompetensi penyuluh pertanian, faktor-faktor yang mempengaruhinya, serta model pengembangan kompetensi penyuluh berbasis pemanfaatan media?. Adapun tujuan penelitian dirumuskan sebagai berikut: (1) menganalisis tingkat kompetensi penyuluh pertanian; (2) menganalisis faktor-faktor apa saja yang dominan mempengaruhi kompetensi penyuluh; dan (3) merumuskan bagaimana model pengembangan kompetensi penyuluh berbasis pemanfaatan media.

\section{METODE PENELITIAN}

Penelitian ini merupakan penelitian eksplanatori (explanatory research) yaitu menjelaskan fenomena yang mempengaruhi pengembangan kompetensi penyuluh berbasis pemanfaatan media. Populasi adalah penyuluh pertanian Pegawai Negeri Sipil (PNS) yang bertugas di daerah pertanian padi (Kabupaten Karawang) dan daerah pertanian sayuran (Kabupaten Garut) Provinsi Jawa Barat. Sampel penyuluh yang bertugas di daerah pertanian padi dilakukan dengan teknik random sampling dan di daerah sayuran dengan sensus, seluruhnya berjumlah 170 penyuluh. Untuk mendapatkan data akurat dilakukan verifikasi data kepada petani yang menjadi klien dari penyuluh tersebut.

Pengumpulan data penelitian ini dilakukan pada bulan Februari s.d. April 2009. Pengumpulan data primer menggunakan angket yang sebelumnya telah teruji validitas dan reliabilitasnya. Data ini juga didukung dengan wawancara mendalam dan observasi guna mempertajam analisis data kuantitatif. Analisis data menggunakan: analisis deskriptif, analisis korelasi, analisis regresi berganda, dan analisis jalur. Untuk memudahkan dalam analisis data ini menggunakan aplikasi SPSS versi 14 .

\section{HASIL DAN PEMBAHASAN}

Mengacu pada pendapat AECT (1986), Anderson (1993), Mc Luhan (Budiargo, 2004), Sadiman (1986), dan Severin and Tankard (2001) media dalam penelitian ini 
dimaksudkan sebagai media belajar yang digolongkan menjadi tiga yaitu media massa, media terprogram, dan media lingkungan.

Intensitas pemanfaatan media dalam meningkatkan kompetensi penyuluh dalam katagori rendah. Secara lebih khusus intensitas pemanfaatan media massa yaitu intensitas pemanfaatan koran, majalah, buku, radio dan internet cenderung rendah, kecuali intensitas pemanfaatan media televisi cenderung tinggi (Tabel 1).

Tabel 1 Sebaran Persentase dan Rataan Skor Pemanfaatan Media Massa

\begin{tabular}{|c|c|c|c|c|c|c|c|c|c|c|c|c|}
\hline \multirow[b]{2}{*}{ Katagori } & \multicolumn{2}{|c|}{ Koran } & \multicolumn{2}{|c|}{ Majalah } & \multicolumn{2}{|c|}{ Buku } & \multicolumn{2}{|c|}{ Radio } & \multicolumn{2}{|c|}{ Televisi } & \multicolumn{2}{|c|}{ Internet } \\
\hline & $\begin{array}{c}\text { Rataa } \\
\mathrm{n} \%\end{array}$ & $\begin{array}{c}\text { Rataan } \\
\text { Skor }\end{array}$ & $\begin{array}{c}\text { Rataan } \\
\%\end{array}$ & $\begin{array}{c}\text { Rataan } \\
\text { Skor }\end{array}$ & $\begin{array}{c}\text { Rataan } \\
\%\end{array}$ & $\begin{array}{c}\text { Rataan } \\
\text { Skor }\end{array}$ & $\begin{array}{c}\text { Rataan } \\
\%\end{array}$ & $\begin{array}{c}\text { Rataan } \\
\text { Skor }\end{array}$ & $\begin{array}{c}\text { Rataan } \\
\%\end{array}$ & $\begin{array}{c}\text { Rataan } \\
\text { Skor }\end{array}$ & $\begin{array}{c}\text { Rataan } \\
\%\end{array}$ & $\begin{array}{c}\text { Rataan } \\
\text { Skor }\end{array}$ \\
\hline Sangat & 72 & 18 & 33 & & 74 & 24 & 75 & 17 & 5 & & 82 & 8 \\
\hline Rendah & & & & & & & & & & & & \\
\hline Rendah & 18 & & 38 & & 11 & & 21 & & 3 & & 11 & \\
\hline Sedang & 7 & & 7 & 54 & 12 & & 3 & & 11 & & 7 & \\
\hline Tinggi & 4 & & 22 & & 4 & & 1 & & 81 & 89 & 1 & \\
\hline Jumlah & 100 & & 100 & & 100 & & 100 & & 100 & & 100 & \\
\hline
\end{tabular}

Keterangan: $0-25=$ Sangat rendah, $26-50=$ Rendah, $51-75=$ Sedang, $76-100=$ Tinggi

Intensitas pemanfaatan media terprogram (Tabel 2) relative rendah. Ini ditunjukkan dari dimensi pemanfaatan media terprogram yaitu intensitas pelatihan dan tingkat pendidikan formal lanjutan yang rendah, kecuali intensitas pertemuan antar penyuluh yang tinggi. Begitu pula intensitas pemanfaatan media lingkungan dalam katagori rendah. Hal ini terlihat dari semua dimensi pemanfaatan media lingkungan yaitu intensitas pengamatan lingkungan alam, intensitas pengamatan lingkungan usahatani, dan intensitas pendalaman inovasi mandiri yang relatif rendah.

Tabel 2 Sebaran Persentase dan Rataan Skor Pemanfaatan Media Terprogram dan Lingkungan

\begin{tabular}{|c|c|c|c|c|c|c|c|c|c|c|c|c|}
\hline \multirow[t]{2}{*}{ Katagori } & \multicolumn{2}{|c|}{$\begin{array}{l}\text { Pendidikan } \\
\text { lanjutan }\end{array}$} & \multicolumn{2}{|c|}{$\begin{array}{l}\text { Pertemuan } \\
\text { Penyuluh }\end{array}$} & \multicolumn{2}{|c|}{ Pelatihan } & \multicolumn{2}{|c|}{$\begin{array}{l}\text { Pengamatan } \\
\text { Alam }\end{array}$} & \multicolumn{2}{|c|}{$\begin{array}{l}\text { Pengamatan } \\
\text { Usahatani }\end{array}$} & \multicolumn{2}{|c|}{$\begin{array}{c}\text { Pendalaman } \\
\text { Inovasi } \\
\text { Mandiri }\end{array}$} \\
\hline & $\begin{array}{c}\text { Rataan } \\
\%\end{array}$ & $\begin{array}{l}\text { Rataan } \\
\text { Skor }\end{array}$ & $\begin{array}{c}\text { Rataan } \\
\%\end{array}$ & $\begin{array}{c}\text { Rataan } \\
\text { Skor }\end{array}$ & $\begin{array}{c}\text { Rataan } \\
\%\end{array}$ & $\begin{array}{r}\text { Rataan } \\
\text { Skor }\end{array}$ & $\begin{array}{c}\text { Rataan } \\
\%\end{array}$ & $\begin{array}{c}\text { Rataan } \\
\text { Skor }\end{array}$ & $\begin{array}{c}\text { Rataan } \\
\%\end{array}$ & $\begin{array}{l}\text { Rataan } \\
\text { Skor }\end{array}$ & $\begin{array}{c}\text { Rataan } \\
\%\end{array}$ & $\begin{array}{c}\text { Rataan } \\
\text { Skor }\end{array}$ \\
\hline $\begin{array}{l}\text { Sangat } \\
\text { Rendah }\end{array}$ & 21 & & 3 & & 71 & 20 & 82 & 16 & 66 & 21 & 1 & \\
\hline Rendah & 28 & 50 & 2 & & 24 & & 15 & & 27 & & 51 & \\
\hline Sedang & 34 & & 18 & & 2 & & 2 & & 8 & & 41 & 51 \\
\hline Tinggi & 17 & & 78 & 93 & 2 & & 1 & & 0 & & 6 & \\
\hline Jumlah & 100 & & 100 & & 100 & & 100 & & 100 & & 100 & \\
\hline
\end{tabular}

\section{Model Pengembangan Kompetensi Penyuluh}

Model pengembangan kompetensi penyuluh berbasis pemanfaatan media dirumuskan berdasarkan hasil uji regresi yang selanjutnya dianalisis melalui analisis jalur (path analysis) (Tabel 3). Melalui analisis jalur diketahui, kompetensi penyuluh secara langsung dipengaruhi oleh: intensitas pendalaman inovasi mandiri, intensitas pelatihan, intensitas pertemuan antar penyuluh, umur, tingkat kondusivitas belajar, motivasi, dan intensitas pemanfaatan majalah. Kompetensi penyuluh juga dipengaruhi secara tidak langsung oleh: pendidikan formal, kepemilikan media komunikasi dan informasi, dan dukungan keluarga melalui pemanfaatan media massa; peubah tingkat pendidikan formal, 
motivasi, dan tuntutan klien melalui pemanfaatan media terprogram; serta tuntutan klien dan pendidikan formal melalui pemanfaatan media lingkungan.

Tabel 3 Koefisien Pengaruh Langsung dan Tidak Langsung terhadap Kompetensi Penyuluh berdasarkan Analisisi Jalur

\begin{tabular}{lccccc}
\hline \multirow{2}{*}{\multicolumn{1}{c}{ Peubah }} & & \multicolumn{2}{c}{ Pengaruh tidak langsung melalui } & \\
\cline { 5 - 6 } & Pengaruh & Media & Media & Media & Pengaruh \\
Langsung & Massa & Terprogram & Lingkungan & Total \\
\hline X11 Usia & 0,171 & - & - & - & 0,171 \\
X12 Pendidikan Formal & - & 0,004 & 0,171 & 0,032 & 0,207 \\
X14 Kepemilikan TKI & - & 0,023 & - & - & 0,023 \\
X15 Motivasi & 0,147 & - & 0,078 & - & 0,225 \\
X21 Dukungan Keluarga & - & 0,025 & - & - & 0,025 \\
X24 Kondusivitas Belajar & 0,169 & - & - & - & 0,169 \\
X25 Tuntutan Klien & - & - & 0,057 & 0,089 & 0,146 \\
Y12 Intensitas Pemanfaatan Majalah & 0,145 & - & - & - & 0,145 \\
Y22 Intensitas Pelatihan & 0,238 & - & - & - & 0,238 \\
Y23 Intensitas Pertemuan Penyuluh & 0,200 & - & - & - & 0,200 \\
Y33 Int. Pendalaman Inovasi Mandiri & 0,392 & - & - & - & 0,392
\end{tabular}

Hasil analisis jalur tersebut selanjutnya dapat dirumuskan model pengembangan kompetensi penyuluh berbasis pemanfaatan media seperti dijelaskan dalam Gambar 1. Ternyata faktor-faktor yang paling berpengaruh terhadap peningkatan kompetensi penyuluh adalah pendalaman inovasi mandiri dengan koefisien regresi 0,392. Hal ini bermakna bahwa intensitas penyuluh mendalami secara mandiri tentang inovasi atau teknologi baru dalam usahatani yang tepat untuk diterapkan di tempat tugasnya sangat penting. Kegiatan ini adalah pendalaman terhadap inovasi atau teknologi baru melalui pengkajian referensi atau buku-buku yang relevan, melakukan ujicoba disesuaikan dengan kondisi di tempat tugas penyuluhan, melibatkan petani, belajar terhadap petani yang berhasil, serta menganalisis petani yang gagal. 


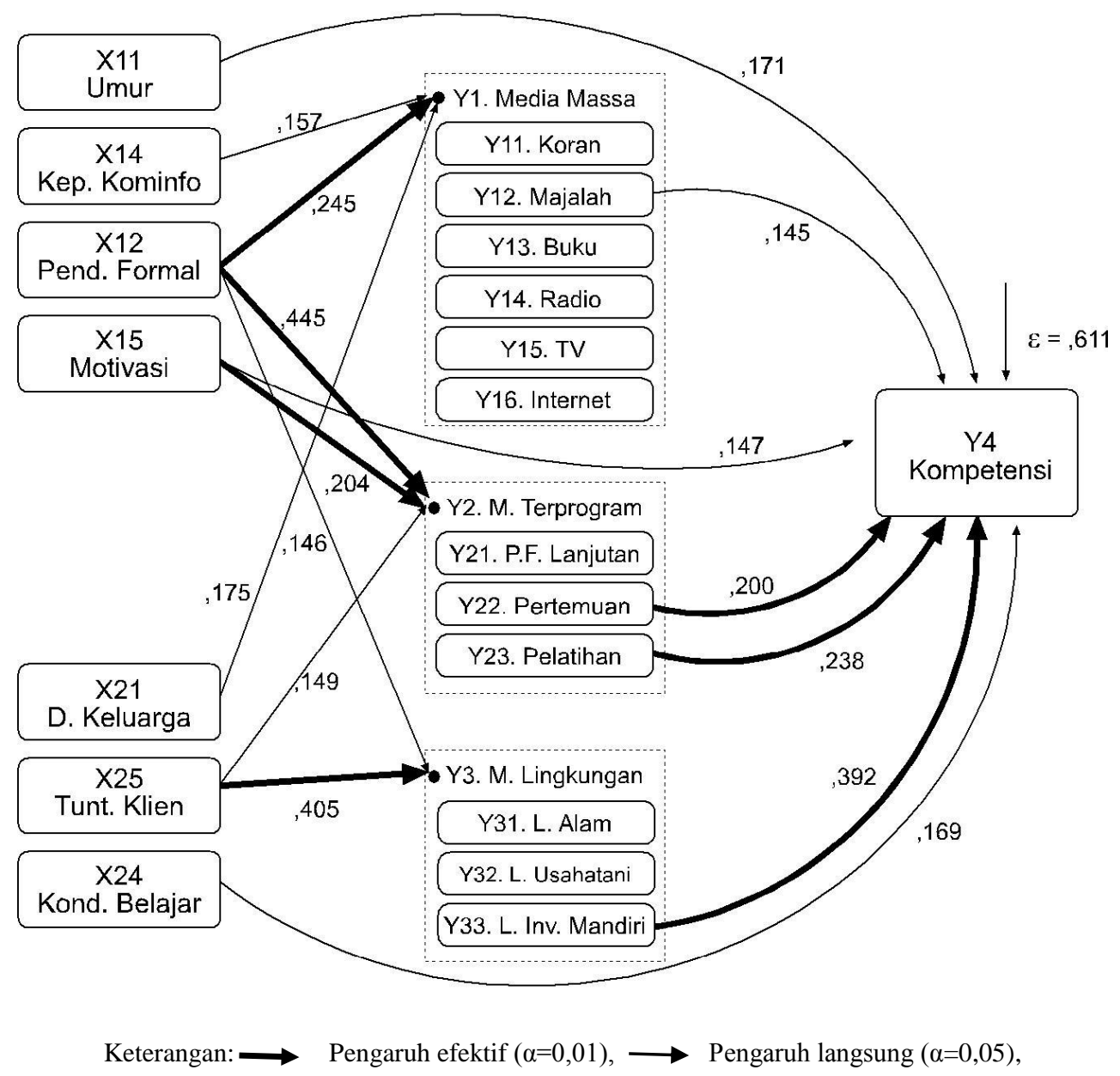

Gambar 1 Model Pengembangan Kompetensi Penyuluh Berbasis Media

Hasil pendalaman di Kabupaten Garut misalnya, seorang penyuluh yang diakui kredibel di petani karena ia sering melakukan ujicoba secara mandiri. Kegiatan uji coba ini dilakukan dengan modal pribadi karena lembaga penyuluhan tidak mampu menyediakan baik lahan maupun biayanya. Hal ini bisa dilakukan secara mandiri karena yang bersangkutan memiliki lahan pertanian yang cukup dan memiliki usaha sayuran. Hasilnya, mampu meningkatkan kemampuannya dalam bidang tanaman sayuran, sehingga menjadi contoh yang diikuti oleh petani di tempat tugasnya.

Pendalaman inovasi mandiri yang merupakan proses belajar mandiri yang dilakukan penyuluh yaitu dengan memanfaatkan berbagai media belajar. Hasil ini menjadi menarik karena pada saat kondisi dukungan pemerintah daerah dan lembaga penyuluhan rendah, sedangkan tuntutan klien/petani terhadap perubahan penyuluhan terus meningkat. Ternyata belajar mandiri memiliki kontribusi yang paling tinggi dalam meningkatkan kompetensi penyuluh. Beberapa penyuluh di Karawang dan Garut melakukan ujicoba tidak hanya dilakukan di lahan percobaan, tetapi juga dapat dilakukan pada lahan petani. Upaya ini bekerjasama dengan petani, biasanya ketua kelompok. Hasil ujicobanya disebarluaskan kepada petani sekitarnya. Dalam hal ini petani percaya karena melihat langsung proses dan hasil usahatani yang dilakukan oleh penyuluh tersebut. Namun kegiatan ujicoba tersebut hanya dapat dilakukan oleh sebagian kecil penyuluh saja, karena keterbatasan anggaran, lahan percobaan, kreativitas, dan dorongan individu penyuluh untuk belajar secara mandiri. Oleh karena itu kompetensi penyuluh masih cenderung rendah (belum sesuai harapan). 
Alasan pendalaman inovasi mandiri merupakan faktor yang sangat dominan dalam meningkatkan kompetensi penyuluh, antara lain: (1) pendalaman inovasi mandiri merupakan upaya penyuluh dalam memahami dan menselaraskan inovasi dan teknologi yang berkembang sesuai dengan kebutuhan petani. Ini adalah prinsip penyuluhan harus didasarkan pada kebutuhan dan permasalahan petani; (2) Pendalaman inovasi mandiri berarti upaya pembuktian cocok tidaknya inovasi dan teknologi baru sesuai dengan kondisi alam dan masyarakat setempat. Ini adalah prinsip bahwa petani lebih percaya pada inovasi dan teknologi baru yang mereka bisa langsung melihatnya; (3) Pendalaman inovasi mandiri merupakan bentuk dari proses belajar mandiri yang dilakukan penyuluh pada saat dukungan pemerintah daerah, lembaga penyuluhan, dan media belajar, dan sarana penunjang peningkatan penyuluhan kurang mendukung; dan (4) Salah satu sifat dasar dari suatu inovasi adalah harus dapat diujicobakan oleh pengguna (Rogers dan Shoemaker, 1987) dalam hal ini oleh penyuluh bersama dengan petani.

Untuk dapat meningkatkan pemanfaatan media lingkungan ini antara lain: (1) kemampuan penyuluh perlu ditingkatkan melalui peningkatan pendidikan formal dan melalui kegiatan pelatihan secara kontinyu; (2) peningkatan kemudahan akses informasi yang terkait dengan penyuluhan dalam hal ini media yang berpengaruh adalah majalah, buku, radio dan media massa lainnya secara kontinyu; (3) peningkatan situasi kerja yang kondusif dalam mendorong penyuluh untuk berprestasi, misalnya melalui penghargaan dan sangsi, distribusi kerja, dan komunikasi yang harmonis antara pimpinan lembaga penyuluhan dengan penyuluh dan sesama penyuluh; (4) menyediakan kemudahan berbagai media belajar seperti: buku, majalah, brosur, radio, TV, dan internet minimal di tingkat BPP sehingga penyuluh terdorong untuk terus belajar menyesuaikan diri dengan perkembangan dan tuntutan klien, dan (5) mendorong penyuluh untuk terus melakukan ujicoba bersama petani dalam meningkatkan usahataninya.

Intensitas pelatihan merupakan urutan kedua faktor yang paling berpengaruh terhadap kompetensi penyuluh. Ini bermakna bahwa intensitas pelatihan penyuluh sangat berperan dalam meningkatkan kompetensi penyuluh. Dengan banyaknya frekuensi pelatihan, berarti penyuluh tidak hanya lebih sering mendapatkan ilmu pengetahuan baru akan tetapi mendapatkan aspek lain yang berguna untuk meningkatkan kemampuanya. Aspek lain tersebut antara lain: berinteraksi dengan nara sumber (instruktur) pelatihan, interaksi dengan sesama penyuluh, memperoleh energi baru (motivasi) untuk belajar, serta informasi terbaru lainnya yang diperlukan dalam penyuluhan. Rendahnya intensitas pelatihan ini menunjukan komitmen pemerintah baik pusat maupun daerah masih lemah dalam meningkatkan kompetensi penyuluh. Padahal pendidikan dan latihan merupakan tanggungjawab pemerintah seperti diamanatkan dalam Undang-undang No. 16 tahun 2006 pasal 21 ayat 1 dijelaskan bahwa pemerintah pusat dan pemerintah daerah berkewajiban meningkatkan kompetensi penyuluh PNS melalui pendidikan dan pelatihan. Ini berarti untuk peningkatan kompetensi penyuluh, diperlukan komitmen pemerintah dalam peningkatan intensitas kegiatan pelatihan secara kontinyu sesuai kebutuhan dan tuntutan masyarakat.

Intensitas pertemuan antar penyuluh ternyata memiliki peran yang penting yaitu terbukti berpengaruh nyata dan langsung dalam meningkatkan kompetensi penyuluh (Gambar 1). Kegiatan ini dilakukan sebulan dua kali, sudah menjadi wahana mendiskusikan masalah-masalah yang di ditemukan lapangan, berbagi (sharing) pengalaman, wahana informasi inovasi/teknologi baru, serta sebagai media komunikasi antar penyuluh dan juga penyuluh dengan pimpinan lembaga penyuluhan.

Dalam perspektif komunikasi massa, pertemuan antar penyuluh dapat menjadi wahana pendalaman dan klarifikasi atas respon penyuluh yang cenderung beragam terhadap terpaan media massa (teori Lazarsfeld dengan teori komunikasi dua tahap (two 
step flow), (teori difusi inovasi Rogers, 1995), dan (teori Kincaid dan Schramm 1987) dan teori spiral keheningan (the spiral of silence) dari Elizabeth Noelle-Neuman, yang menekankan bahwa pendapat umum ditentukan oleh proses saling mempengaruhi antara komunikasi massa, komunikasi antar pribadi, dan persepsi individu tentang pendapatnya dalam hubungannya dengan pendapat orang-orang lain di sekitarnya (Severin dan Tankard, 2001). Oleh karena itu untuk meningkatkan kompetensi penyuluh kegiatan pertemuan antar penyuluh dapat ditingkatkan baik intensitasnya maupun mutu dari setiap pertemuan tersebut. Melibatkan kelompok tani dan tokoh masyarakat dalam pertemuan dapat lebih bagus, karena mereka bisa berdikusi secara langsung permasalahan yang dihadapi petani dan sekaligus mencari solusi yang tepat.

Umur merupakan salah satu karakteristik pribadi penyuluh yang berpengaruh langsung terhadap kompetensi. Umur berbanding lurus dengan pengalaman kerja. Artinya semakin tua umurnya, maka pengalaman bekerja juga semakin lama, sehingga kompetensinya juga semakin baik. Dengan kata lain penyuluh senior kompetensinya lebih baik dibandingkan dengan penyuluh yunior, karena logikanya mereka lebih berpengalaman. Oleh karena itu memang logis apabila umur memiliki pengaruh nyata terhadap kopetensi penyuluh. Ini adalah tantangan bagi penyuluh muda untuk dapat ditingkatkan sehingga memiliki kompetensi yang relatif sama dengan penyuluh senior.

Tingkat dukungan kondusivitas belajar di lembaga penyuluhan ternyata memiliki pengaruh langsung terhadap peningkatan kompetensi penyuluh. Oleh karena itu salah satu upaya untuk meningkatkan kompetensi penyuluh adalah lembaga penyuluhan menciptakan organisasi yang dapat mendorong dan menciptakan penyuluh untuk terus belajar. Hal dapat dilakukan melalui: dorongan dan kemudahan untuk melanjutkan pendidikan formal, pelatihan, menyediakan bahan belajar, memfasilitasi kemudahan akses informasi, serta dukungan untuk melakukan ujicoba inovasi, serta dorongan untuk memanfaatkan berbagai media belajar yang dapat dilakukan secara mandiri. Penelitian ini juga menunjukkan bahwa dukungan kondusivitas belajar masih rendah dengan rataan skor hanya 40 (Tabel 4), sehingga kompetensi penyuluh juga rendah.

Motivasi berpengaruh nyata dan langsung terhadap peningkatan kompetensi penyuluh. Ini menunjukkan motivasi memiliki peran yang penting dalam mengembangkan kompetensi penyuluh. Teori motivasi kerja Herzberg (Pace dan Faules, 1993) menegaskan dua hal yang memuaskan kebutuhan manusia, yaitu, (1) kebutuhan yang berkaitan dengan kepuasan kerja seperti prestasi, penghargaan, tanggungjawab, kemajuan/promosi, pekerjaan itu sendiri, dan potensi bagi pertumbuhan pribadi; dan (2) kebutuhan yang berkaitan dengan ketidakpuasan kerja seperti gaji, pengawasan, keamanan kerja, kondisi kerja, administrasi, kebijakan organisasi, hubungan antara pribadi baik atasan, rekan kerja, maupun bawahan. Dikaitkan dengan hasil penelitian ini yang mana skor rataan motivasi cenderung sedang, ini berarti faktor-faktor yang terkait dengan kepuasan kerja dan faktorfaktor yang berhubungan dengan ketidakpuasan kerja masih kurang ditanggapi secara positif, sehingga motivasi penyuluh masih belum sesuai dengan yang diharapkan (tinggi). Padahal motivasi ini berpengaruh langsung terhadap kompetensi penyuluh. Oleh karena itu untuk meningkatkan kompetensi, faktor-faktor yang dapat meningkatkan motivasi tersebut perlu ditingkatkan.

Media massa yang berpengaruh nyata dan langsung terhadap kompetensi hanya majalah (Gambar 1). Hasil pendalaman diketahui bahwa majalah yang dimiliki dan sering dibaca penyuluh adalah Majalah Sinar Tani. Majalah ini memiliki subtansi yang sesuai dengan penyuluhan dan terbit dua kali dalam sebulan oleh Departemen Pertanian serta didistribusikan kepada penyuluh PNS secara kontinyu. Hal ini bermakna bahwa media massa yang subtansinya dirancang secara khusus dan dilakukan secara kontinyu ternyata mampu secara signifikan meningkatkan kompetensi penyuluh pertanian. Implikasinya 
untuk meningkatkan kompetensi penyuluh salah satunya melalui pemanfaatan media massa yang dirancang dan dilakukan secara kontinyu.

Media massa lain seperti: koran, buku, radio, televisi, dan internet memiliki karakteristik kelemahan dan kelebihannya masing-masing. Oleh karena itu pemilihan media massa yang tepat, disesuaikan dengan kebutuhan dan dukungan sarana lainya. Yang menarik dari temuan di sini adalah pemanfaatan media televisi oleh penyuluh sangat tinggi dengan rataan skor mencapai hampir 90 persen. Artinya penyuluh hampir tiap hari menonton televisi, namun subtansi acara televisi masih didominasi oleh hiburan, padahal media ini memiliki potensi besar untuk tujuan pendidikan. Hasil-hasil penelitian telah membuktikan bahwa media televisi memiliki pengaruh positif terhadap hasil pendidikan (Wilkinson, 1980), (Anwas, 2000). Secara lebih khusus, media televisi telah dimanfaatkan secara penuh di negara China untuk pendidikan penyuluh dan petani yang tersebar di seluruh daratan RRC.

Asumsi bahwa tingkat pendidikan formal berpengaruh langsung terhadap kompetensi ternyata tidak terbukti dalam penelitian ini. Gambar 1 menunjukkan bahwa pendidikan formal tidak berpengaruh langsung terhadap kompetensi penyuluh. Pendidikan formal memiliki pengaruh tidak langsung secara signifikan melalui pemanfatan media massa, media terprogram, dan media lingkungan. Di sisi lain total pemanfatan media massa, media terprogram, dan media lingkungan berpengaruh secara signifikan terhadap kompetensi. Kondisi ini dapat diartikan bahwa meningkatnya pendidikan formal penyuluh belum bisa meningkatkan kompetensi penyuluh. Untuk dapat meningkatkan kompetensi ini lulusannya masih perlu menempuh proses belajar melalui ketiga media belajar tersebut yaitu media massa, media terprogram, dan media lingkungan. Cara lainnya adalah lembaga pendidikan formal yang menyiapkan tenaga penyuluh terutama kurikulum dan proses pembelajarannya perlu disesuaikan dengan pengalaman belajar yang dilakukan melalui ketiga media belajar tersebut, antara lain proses pembelajaran tidak hanya dalam tataran teori akan tetapi dipadukan dengan praktek dan masalah-masalah pertanian yang terjadi dan dibutuhkan petani di lapangan.

Kepemilikan media komunikasi dan informasi merupakan wujud kedekatan (familiarity) dengan media tersebut sehingga memiliki peluang besar untuk memanfaatkannya dibandingkan dengan yang belum memilikinya. Asumsi ini terbukti dalam penelitian ini, tingkat kepemilikan media komunikasi dan informasi berpengaruh terhadap pemanfaatan media massa yang selanjutnya berpengaruh terhadap peningkatan kompetensi penyuluh. Ini berarti kepemilikan media komunikasi dan informasi memiliki pengaruh tidak langsung melalui pemanfaatan media massa terhadap peningkatan kompetensi penyuluh pertanian. Implikasinya bahwa untuk meningkatkan kompetensi penyuluh, komunikasi dan informasi seperti: koran, majalah, brosur, radio, televisi, internet, $\mathrm{hp}$, dan lainya perlu diupayakan untuk dimiliki oleh penyuluh atau minimal di lembaga penyuluhan diberikan kemudahan untuk memanfaatkan media komunikasi dan informasi tersebut.

Dukungan keluarga yang diukur melalui tingkat dukungan finansial dan dukungan moril anggota keluarga terhadap peningkatan kompetensi penyuluh memiliki pengaruh tidak langsung melalui pemanfaatan media massa. Ini memang logis bahwa untuk memanfaatkan media massa diperlukan dukungan finansial dan moril dari keluarga untuk bisa mengakses media massa tersebut. Dalam hal ini faktor ekonomi keluarga penyuluh perlu ditingkatkan, di sisi lain kesadaran keluarga terhadap profesi penyuluh juga perlu mendapatkan perhatian, sehingga keluarga mereka dapat mendukung kepada tugas suami/istri atau orangtuanya sebagai penyuluh.

Tuntutan klien/petani terhadap penyuluh untuk melakukan perubahan dalam menerapkan inovasi atau teknologi baru secara nyata berpengaruh tidak langsung terhadap 
kompetensi penyuluh melalui pemanfaatan media terprogram dan media lingkungan. Rataan skor tuntutan klien/petani dalam perubahan dan penerapan inovasi atau teknologi baru dalam penyuluhan mencapai katagori sedang. Ini berarti tuntutan sasaran/masyarakat cukup rumit.

Tuntutan petani untuk perubahan dalam penyuluhan dipandang sebagai sebuah tantangan. Semakin rumitnya tuntutan atau tantangan petani seiring perkembangan zaman, menuntut kesadaran penyuluh untuk terus belajar. Untuk memenuhi tantangan tersebut, penyuluh dituntut untuk meningkatkan kemampuannya melalui proses belajar. Sebaliknya penyuluh yang menganggap tuntutan tersebut sebagai masalah, sehingga kurang terdorong untuk belajar, akibatnya kemampuannya tidak bisa memenuhi harapan petani. Belajar dalam hal ini tidak harus di bangku kuliah, tetapi belajar yang nyata adalah di lapangan dengan masyarakat. Penelitian ini membuktikan bahwa tingkat pendidikan formal tidak berpengaruh secara langsung dan nyata terhadap peningkatan kompetensi penyuluh. Mungkin saja jenjang pendidikan formal sudah cukup, akan tetapi karena kurang melakukan pendalaman di lapangan sehingga kompetensinya masih belum sesuai harapan petani. Dengan kata lain penyuluh harus banyak belajar dengan alam dalam meningkatkan kemampuannya.

Ternyata dukungan pemerintah daerah dan lembaga penyuluhan terhadap peningkatan kemampuan penyuluh rendah. Begitu pula akses informasi dan substansi informasi yang terkait dengan penyuluhan masih rendah. Di sisi lain pemanfaatan media yang dilakukan oleh penyuluh baik media massa, media terprogram, dan juga media lingkungan masih cenderung rendah. Akibatnya kompetensi penyuluh baik di daerah petani padi (Karawang) dan daerah petani sayuran (Garut) sama-masa rendah. Oleh karena itu terbukti dalam penelitian ini bahwa faktor yang paling besar pengaruhnya terhadap peningkatan kompetensi penyuluh adalah intensitas pendalaman inovasi mandiri. Artinya penyuluh yang memiliki kompetensi baik adalah penyuluh yang sering melakukan belajar mandiri dengan memanfaatkan berbagai media belajar apapun yang tersedia di sekitarnya. Dengan kata lain faktor utama peningkatan kompetensi penyuluh adalah meningkatkan kemandirian belajar bagi penyuluh. Tantangan bagi lembaga penyuluhan dan pihak terkait lainnya adalah bagaimana mendorong dan menciptakan penyuluh untuk tumbuh dan melakukan kemandirian belajar, kapanpun dan dimanapun.

\section{KESIMPULAN}

Tingkat kompetensi penyuluh cenderung rendah, hal ini terlihat dari semua dimensi kompetensi yaitu: kemampuan pemahaman potensi wilayah, kemampuan pengelolaan pelatihan, kemampuan pengelolaan pembelajaran, kemampuan pengelolaan komunikasi inovasi, kemampuan pengelolaan kewirausahaan, kemampuan pengelolaan pembaharuan, dan kemampuan pemandu sistem jaringan dalam katagori rendah.

Rendahnya tingkat kompetensi ini dipengaruhi oleh: intensitas pendalaman inovasi mandiri, intensitas pelatihan, intensitas pertemuan antar penyuluh, dukungan kondusivitas belajar dalam lembaga penyuluhan, motivasi, dan intensitas pemanfaatan majalah yang cenderung rendah, meskipun umur penyuluh dalam katagori tua/senior.

Model pengembangan kompetensi penyuluh berbasis pemanfaatan media dilakukan melalui peningkatan paubah-paubah yang berpengaruh baik langsung maupun tidak langsung terhadap kompetensi penyuluh. Adapun peubah-peubah yang dimaksudkan adalah intensitas pendalaman inovasi mandiri, intensitas pelatihan, intensitas pertemuan antar penyuluh, dukungan kondusivitas belajar dalam lembaga penyuluhan, motivasi, dan intensitas pemanfaatan majalah yang cenderung rendah, umur, pendidikan formal, kepemilikan media komunikasi dan informasi, dan dukungan keluarga, motivasi, dan 
tuntutan klien sebagai tantangan perubahan terhadap penyuluh untuk meningkatkan kompetensinya.

\section{DAFTAR PUSTAKA}

AECT. 1986. Definisi Teknologi Pendidikan; Satuan Tugas Definisi dan Terminologi AECT. Jakarta: Rajawali.

Anderson, Ronald H. 1993. Selecting and Developing Media for Instruction, Van Nostrand Reinhold Company, Inc.

Anwas, Oos M. 2000. Studi Evaluatif Pemanfaatan Video Pembelajaran Sekolah dalam Proses Pembelajaran. Jurnal Teknodik. Depdiknas.

Boyatzis, RE. 1984. The Competent Manager: A Model for Effective Performance. New York: Jihn Willy \& Sons.

Budiargo, Dian. 2004. Media Equation dalam Pembelajaran. Makalah Seminar Nasional Teknologi Pendidikan. Depdiknas. Jakarta 1 s.d. 2 Desember 2004.

Kincaid, D. Lawrence dan Wilbur Schramm. 1987. Asas-Asas Komunikasi Antar Manusia. Edisi Indonesia. Jakarta: LP3ES.

Pace, R. Wayne and Don F. Faules. 1993. Komunikasi Organisasi: Strategi Meningkatkan Kinerja Perusahaan. Edisi Indonesia. Bandung: Remaja Rosdakarya.

Rogers, Everett M. 1995. Diffusion of Innovations. Fourh Edition. New York:The Free Press.

Sadiman, Arief S. 1986. Media Pendidikan; Pengertian, Pengembangan, dan Pemanfaatanya. Jakarta: Rajawali.

Severin, J Werner dan James W. Tankard. 2001. Communication Theory: Origin, Methods, and Uses in The Mass Media. Eddison Wesley Lngman, Inc.

Spencer, M. Lyle and M. Signe Spencer. 1993. Competence at Work: Models for Superrior Performance, John Wily \& Son, Inc. New York, USA.

Slamet, Margono. 2008. Menuju Pembangunan Berkelanjutan melalui Implementasi UU No. 16 tahun 2006 tentang Sistem Penyuluhan Pertanian, Perikanan, dan Kehutanan. Dalam Pemberdayaan Manusia Pembangunan yang Bermartabat. Penyunting: Adjat Sudrajat dan Ida Yustina. Bogor: Pustaka Bangsa Press.

Sumardjo, 1999. Transformasi Model Penyuluhan Pertanian Menuju Pengembangan Kemandirian Petani. Disertasi Sekolah Pascasarjana IPB. Bogor.

2006. "Kompetensi Penyuluh." Makalah disampaikan pada Pertemuan KPPN

dengan Departemen Pertanian di Batam pada April 2006.

Sumardjo. 2008. Penyuluhan Pembangunan Pilar Pendukung Kemajuan dan Kemandirian Masyarakat. Dalam Pemberdayaan Manusia Pembangunan yang Bermartabat. Penyunting: Adjat Sudrajat dan Ida Yustina. Bogor: Pustaka Bangsa Press.

Undang-undang No. 16 tahun 2006 tentang Sistem Penyuluhan Pertanian, Perikanan, dan Kehutanan.

Wilkinson, Gene L. 1980, Media dalam Pembelajaran; Penelitian Selama 60 Tahun, Edisi Indonesia, Jakarta: CV Rajawali. 